\title{
Soğuk Savaş Düzeninin Sosyal Politikaları: Bir Yumuşak Güiç Unsuru Olarak Yakın ve Orta Doğu Çalışma Enstitüsü ve Türkiye'nin Bölgesel Rolü
}

\author{
Social Policies of the Cold War Order: The Labor Institute for Near \\ and Middle East as a Soft Power Instrument and the Regional Role of \\ Turkey
}

\author{
Emine Tutku VARDAĞLI*
}

\section{Öz}

Bu çalışma güvenlik odaklı Soğuk Savaş literatürüne bir alternatif olarak, dönemin uluslararası sosyal politikalarını ve bu yolla Türkiye’nin dönüşen bölgesel konumunu ve misyonunu ele almaktadır. Spesifik olarak, Türkiye’nin önce Yakın Doğu daha sonra Orta Doğu olarak adlandırılan açık uçlu siyasi coğrafyada, Uluslararası Çalışma Örgütü (ILO) aracılığıyla üstlendiği bölgesel rol incelenmektedir. ILO'nun 1950'lerin başında İstanbul'da kurduğu Yakın ve Orta Doğu Çalışma Enstitüsü (YODÇE), hem Türkiye'de hem de bölgede Soğuk Savaş düzeninin sosyal politika normlarını belirleyen uluslararası bir örgüt olarak mercek altına alınmıştır. Siyasal-örgütsel literatür içinde pek az bilinen bu enstitünün yeni oluşan uluslararası düzen açısından etkin bir siyasi manevra alanı olarak işlev gördüğüne dikkat çekilmektedir. Söz konusu enstitü daha ziyade bölgesel bir yumuşak güç unsuru olarak tanımlanmakta, böylelikle genellikle Soğuk Savaş sonrası ortaya çıktığı düşünülen yumuşak güç siyasetinin kökenine inilmektedir. Bu bağlamda, Türkiye’nin Soğuk Savaş düzeni içinde sosyal politika üzerinden işlevselleştirilen yumuşak güç siyasetinin hem aracı hem de alanı haline geldiği tespit edilmektedir. Yöntemsel anlamda, siyasi tarihin verilerinden hareket eden ve yorumsamacı bir yaklaşımla diplomasinin satır aralarını okuyan bu çalışma, aynı zamanda uluslararası ilişkiler literatüründe "yumuşak güç" kavramına derinlik katmayı amaçlamaktadır.

Anahtar Kelimeler: Soğuk Savaş, Sosyal Politika, Yumuşak Güç, Türkiye’nin Bölgesel Rolü, Yakın ve Orta Doğu Çalışma Enstitüsü, Uluslararası Çalışma Örgütü

\begin{abstract}
As an alternative to the security centered Cold War literature, this study tackles with the international social policies of the period and in this way, it discusses the changing regional position and mission of Turkey. Specifically, the regional role assumed by Turkey through the agency of the International Labor Organization (ILO) in an open-ended political geography first named as Near East and then Middle East, is investigated in-depth. The Labor Institute for Near and Middle East that was established in İstanbul by the ILO at the beginning of 1950s is examined closely, as an international organization
\end{abstract}

* İstanbul Aydın Üniversitesi, E-posta: etutkuvardagli@aydin.edu.tr 
determining the social policy norms of the Cold War order both in Turkey and in the above-mentioned region. It is indicated that this Institute, which is very little known in the political-organizational literature, functioned as an influential political maneuvering space. The mentioned institute is defined rather as a regional soft power element. Thus, the study retraces soft power politics, which is generally taken so far as a post-Cold War phenomenon. In this context, it is ascertained that Turkey became both the space and instrument of the soft power politics put in operation through social policies in the Cold War order. Methodologically, relying on the inputs of political history and reading the line spaces of diplomacy with an interpretive approach, this study aims at elaborating the notion of soft power in international relations literature.

Keywords: Cold War, Social Policy, Soft Power, Regional Role of Turkey, The Labor Institute for Near and Middle East, Labor Institute, International Labor Organization

\section{Giriş}

Genellikle iki kutupluluk ve güvenlik ekseninde ele alınan Soğuk Savaş anlatısının sosyal politika boyutunun birkaç öncü çalışma dışında gölgede kaldığı görülmektedir (Metinsoy, 2013; Örnek, 2015). Bu noktada, meselenin bu yönüyle ele alınmamasını açıklayan bazı unsurlar öne sürülebilir. Örneğin, bir yanda liberal kutbun sosyal politika alanına mesafeli yaklaşımının (Andrews \& Reisch, 1997), diğer yanda sosyalist kutbun kendi içinde kurduğu düzenin sosyal politika meselelerini önemsizleştirdiği söylenebilir. Dolayısıyla, Soğuk Savaş düzeni içinde sosyal politikaya yeterince yer verilmemiştir. Diğer taraftan, Soğuk Savaşın insanlığın varoluşunu tehdit eden unsurları karşısında, güvenlik dışı söylemler önemsiz ayrıntılar olarak devre dışı kalmış olabilir. Dolayısıyla, Soğuk Savaş dönemi sosyal politikaları pek az tartışılmıştır, fakat bu durum söz konusu alanın Soğuk Savaş bağlamının dışında kaldığı anlamına da gelmez.

Bu çalışmada, Soğuk Savaş dönemi sosyal politika programları yumuşak güç unsurları olarak tanımlanmaktadır. Özellikle çalışma ilişkileri ve sendikal hareketler bağlamında yumuşak güç unsurlarının Soğuk Savaş döneminde devrede olduğuna dikkat çekilmektedir. Bu unsurların Türkiye aracılığıyla yakın geçmişte Yakın Doğu günümüzde ise Orta Doğu olarak anılan bölgeye yansımaları ele alınmaktadır. Ayrıca, Türkiye’ye biçilen bu "bölgesel yumuşak güç merkezi” rolü, ülkenin iç siyasi dinamikleriyle de ilişkilendirilmekte ve böylelikle Türkiye’nin uluslararası sistem içindeki rolüne ve uluslararası örgütlerle kurduğu ilişkilere dair bütüncül bir tablo sunulmaktadır.

\section{Soğuk Savaş Döneminde Sosyal Politika}

\subsection{Batı ve Doğu Bloğu'nda Sosyal Politikalar}

Bu çalışmada, Soğuk Savaş dönemi sosyal politikaları kendinde bir amaçtan ziyade bir siyasi meşruiyet alanı olarak kavramsallaştırılmaktadır. İlk bakışta ilgisiz ya da önemsiz gibi gözüken sosyal politika meselelerini aslında her iki bloğun da kendi manevra alanı içinde etkin bir şekilde işlevselleştirdiğine dikkat çekilmektedir. Bir yandan ABD’nin Orta Doğu'da Sovyetler Birliği’ne meyleden ülkeleri ve Bağlantısızları elde tutma girişimleri (Balkılıç, 2018), diğer yandan Sovyetler Birliği’nin piyasa sosyalizmini tartışan Doğu Avrupảyı yatıştırma çabaları, sosyal politika alanını 
Soğuk Savaş düzeninin adeta bir dip dalgası konumuna getirmiştir (Patterson, 2011). Sonuç olarak, Soğuk Savaş düzeni içinde sosyal politika söylemlerini ve programlarını çift kutuplu bir olgu olarak değerlendirmek mümkündür. Ancak, bu çalışmada söz konusu politikalar Türkiye’nin dahil olduğu liberal Batı bloğu açısından değerlendirilmektedir.

Soğuk Savaş düzeni içinde uluslararası kuruluşları ve "bilimsellik" söylemini arkasına alan iktidarlar, araştırma ve kalkınma enstitülerinin sosyal politika programları aracılığıla bir yumuşak güç zemini oluşturmuştur (Başkaya, 1997). Uluslararası Çalışma Örgütü (ILO) tarafından 1955 yılında İstanbul'da kurulan Yakın ve Orta Doğu Çalışma Enstitüsü de bu bağlamda değerlendirilmektedir. Söz konusu enstitünün Türkiye’nin kendi bölgesinde bir "yumuşak güç” unsuru olarak devreye sokulmasında etkili olduğu öne sürülmektedir.

\subsection{Soğuk Savaş Döneminde Yumuşak Güç Kullanımı}

Uluslararası ilişkiler literatüründe, yumuşak güç kullanımı hem genel olarak hem de Türkiye özelinde Soğuk Savaş sonrası devreye giren bir strateji olarak ifade edilmiştir (Nye, 1990; Çavuş, 2012). Ancak, bu kavramın 1990’ların başında tedavüle girmiş olması, daha öncesinde yumuşak güç unsurlarının pratikte kullanılmadığı anlamına gelmez. Fakat akademik çevrelerin nükleer tehdit gibi en yüksek perdeden kendisini dayatan güç mücadeleleriyle uğraşırken başka türden güç mücadelelerini gözden kaçırdığı anlamına gelebilir. Yumuşak güç kavramının, nükleer güç siyasetinin perdelemesi ortadan kalktıktan sonra bilimsel anlamda adının konulabilmesi de bu bağlamda manidardır.

Zaten yumuşak güç kavramını Soğuk Savaş sonrası ortaya çıkan bir yaklaşım olarak tanıtan ve bizzat literatüre kazandıran Nye’ın kendisi de 2008 tarihli bir çalışmasında yumuşak güç ve kamu diplomasisi ilişkisini incelerken, "Uzun bir geçmişe sahip olan kamu diplomasisi bir ülkenin yumuşak gücünü destekleyen bir araç olarak Soğuk Savaş’ın kazanılmasında başlıca rolü oynamıştır” ifadesiyle mantık olarak yumuşak güç siyasetinin Soğuk Savaş döneminde de kullanıldığını kabul etmek zorunda kalmıştır (Nye, 2008, s.94). 2009 tarihli bir başka çalışmasında ise yumuşak güç kavramını doğrudan ABD Başkanı Eisenhower’ın bir sözüne referansla tanımlamaktadır: "Liderlik, insanlara sadece talimat vererek ya da yaptırım uygulayarak bir şey yaptırtmak değil, fakat aynı zamanda içgüdüsel olarak bunu yapmak istemelerini sağlamaktır” (Nye, 2009, s.161).

Bu çalışmada ele alınan Yakın ve Orta Doğu Çalışma Enstitüsü bir yumuşak güç unsurundan ziyade alternatif olarak bir ideolojik araç ya da kamu diplomasisi aracı olarak ta değerlendirilebilirdi. İdeoloji kavramından yola çıkacak olursak, siyaset alanını adeta özetleyen böylesi devasa kavramları kullanırken dikkatli olmak gerekir. Çünkü böylesi genel kavramlar özelleştirilmeden kullanıldığında fazlasıyla yüzeysel sonuçlara ulaşılmaktadır. Gramsci ve Althusser çağdaş literatürde ideoloji kavramını enine boyuna tartışan düşünürlerin başında gelmekle birlikte, günümüzde pek çok çalışmaya da teorik anlamda kaynaklık etmektedir. Gramsci ideolojiyi bir üst yapı unsuru olarak kültür aracılığıyla topluma nüfuz eden ve değerler sistemini ekonomik 
altyapıyla uyumlu hale getiren bir kavram olarak tanımlamıştır (Gramsci, 1975, s.150-151). Althusser ise devlet aygıtı tarafından bunun nasıl araçsallaştırıldığına dikkat çekmektedir (Althusser, 1971). Yine bu ekolün takipçilerinden Williams ise bir adım daha ileri giderek ideolojinin popüler kültür aracılığıyla kitle iletişim araçlarını kullanarak pratikte nasıl işlediğini göstermiştir (Williams, 1953). Dolasıyla, ideolojinin hem tanımı hem de pratiği kültürel alanla ilişkilidir. Söz konusu enstitü ise ileriki bölümde daha detaylı bir biçimde ele alınacağı üzere, kültürel değil bilimsel söylemi arkasına alarak yol almıştır. Buna göre, YODÇE’yi bir ideolojik araç olarak tanımlasaydık, bugün popüler kültür vasıtasıyla Soğuk Savaş neslinin toplumsal hafızasında yer etmiş bir kurumdan söz ediyor olurduk ki günümüzde bilimsel çevrelerde dahi pek az bilinen bir kurumdan söz ediyoruz. Bu durumda zaten, YODÇE’nin arkasındaki ABD politikası ya da genel anlamda Batı bloğu da propaganda aracı olarak bilim-teknik bülteni gibi belirli bir kesime hitap eden ve sıklıkla politika yapıcıları hedef alan bir yayın organını değil, mesela çizgi roman gibi doğrudan toplumsal değerleri hedefleyen çok daha yaygın kitle iletişim araçlarını seçmiş olurdu. O vakit, YODÇE yayınlarının da sosyalist düşman imgesiyle kitlelere bilinçaltı mesaj veren Ten Ten çizgi romanı gibi popüler yayınlar olması beklenirdi (Assouline, 2009; Apostolides, 2010).

Bu durumda, YODÇE’nin izlediği yola bakarak bir kamu diplomasisi aracına da benzediğini söyleyebiliriz. Ancak bu noktada da bazı ayırt edici unsurları gözden kaçırmamak gerekir. Yumuşak güç gibi yine genç bir kavram olan kamu diplomasisi, ilk kez 1970’lerde ABD’de siyasi pratiğe yönelik ve farklı propaganda unsurlarını içeren bir kavram olarak literatüre girmiştir. Kavramın analitik sınırlarının belirsizliği günümüzde hararetli tartışmalara yol açmaktadır (Gilboa, 2008, s.56). O nedenle, kamu diplomasisi kavramının ekseriyetle kullanıldığı bağlama odaklanmak en azından kavramın ana hatlarını çizmek açısından daha faydalı bir girişim olarak gözükmektedir. Bu açıdan bakıldığında, kamu diplomasisi hali hazırda masada bulunan diplomatik bir meselenin taraflarına daha çok siyasi kampanya yöntemlerini kullanarak kamuoyu baskısı şeklinde destek sağlama girişimleri olarak karşımıza çıkmaktadır (Ross, 2002). Bu yönüyle kamu diplomasisinin daha çok ikili diplomatik ilişkilerde, özellikler Arap-İsrail, Kıbrıs meseleleri gibi çatışma-çözümü bağlamında kullanıldığı gözlenmektedir (Snow ve Cull, 2020).

Yukarıda Nye’a referansla değinildiği üzere, kamu diplomasini bir yumuşak güç aracı olarak tanımlayan çalışmalar ağırlıktadır (Hayden, 2012; Wang, 2011). Ancak, özellikle günümüzde kamu diplomasisinin tek yumuşak güç aracı olmadığı anlaşılmaktadır. Yakın dönemli çalışmalar, ülkelerin uluslararası imajını yönetme amaçlı iletişim ve pazarlama stratejilerini de kamu diplomasisi kavramı içinden ifade edebilmektedir (Pamment, 2014; Potter, 2009). Sonuç olarak, yumuşak güç siyasetinin farklı stratejiler ve araçlarla kendini ortaya koyabileceği anlaşılmaktadır. $\mathrm{Bu}$ çalışma eldeki malzemeyi kamu diplomasisi ya da farklı türden yumuşak güç stratejilerinden birinin kalıbına sığdırmaya çalışmaktan kaçınarak, meseleyi araçsal değil ereksel bir noktadan ele almaktadır. Bu nedenle, YODÇE’yi yalnızca bir yumuşak güç unsuru olarak tanımlamak sosyal politika ve uluslararası düzen arasındaki ilişkiyi ortaya koymak açısından yeterince elverişli bir zemin oluşturmaktadır. 


\subsection{Bir Yumuşak Güç Enstrümanı olarak YODÇE}

1952 yılında Yakın ve Orta Doğu Faaliyet Merkezi çerçevesinde yapılan pilot çalışmalar 1955 yılında YODÇE’nin kurulmasına zemin hazırlamıştır. Enstitü 1955-59 yılları arasında ILO eliyle yönetilmiş, 1960 yılında öngörüldügü gibi Türkiye Cumhuriyeti hükümetine devredilmiştir. Konum olarak İstanbul'un seçilmesinde, kentin çevre ülkelerine ulaşım kolaylığg ve içinde barındırdığı sanayi kuruluşlarının görece fazlalığı etkili olmuştur (Cam, 2008a).

Enstitü’nün ismi Soğuk Savaş’in yarattı̆̆ı siyasi, bölgesel kırılmaya işaret etmesi bakımından dikkat çekicidir. Bölgesel siyaset açısından Yakın Doğu’dan Orta Doğu’ya geçiş sürecini kurumsal anlamda ifade eden Enstitü, misyon açısından da özellikle post-kolonyal dönemde zaman zaman Sovyetlere meyleden Orta Doğu ülkelerinin ideolojik anlamda çevrelenebilmeleri açısından önemli bir rol oynamıştır.

Bu noktada vurgulanması gereken husus, bu Enstitü’nün Türkiye ve bölge ülkelerinde özellikle II. Dünya Savaşı sonrasında oluşan ekonomik daralma ve siyasi dönüşümün yol açtığı toplumsal muhalefeti yönlendiren bir kanal açmış olmasıdır. Enstitü’nün özellikle işçi-işveren ve devlet arasındaki ilişkiyi düzenlemeye yönelik faaliyetleri ve bu yöndeki kurumsallaşma çabaları bölgede oluşan muhalefeti "yatıştırıcı" bir politika aracı olarak işlev görmüştür. II. Dünya Savaşı ertesinde girişilen bu çabanın arka planında, I. Dünya Savaşı ertesinde devreye giren uluslararası kuruluşlar ve onların uygulamaları bulunmaktadır.

Birinci Dünya Savaşı ertesinde Türkiye’nin çevresinde konumlanan az gelişmiş ülkelerde yaşanan ekonomik sorunların geniş çaplı toplumsal muhalefete dönüşmemesini sağlayan en önemli unsur kolonyal yönetimler, onlarla eşgüdümlü çalışan uluslararası kuruluşlar ve insani yardım kuruluşlarıydı (Grabill, 1971). Bugün Orta Doğu dediğimiz, dönem itibarıyla Yakın Doğu’nun bir parçası olarak anılan Suriye ve Lübnan gibi ülkelerde iki savaş arası dönemde yoğun insani yardım faaliyetleri sürdürülmekteydi (Penrose, 1941; Thompson, 2000; Sbaiti, 2008; Khoury, 2014). İnsani yardım örgütlerinin faaliyetleri bu dönemde bu ülkelerle sinırlı olmayıp henüz Yakın Doğu coğrafyası içinde değerlendirilen Yunanistan'da da oldukça etkindi (Aldcroft, 2016). Örneğin, Yunanistan'da 1922'de mültecilere yardımla başlayan uluslararası insani yardım hareketi giderek barınma, sağlık, üretim, istihdam ve eğitim alanlarına yayılarak devletin sosyal politika alanını yapılandırmıştı. Milletler Cemiyeti’nin mültecilere yardım amacıyla ülkede kurduğu Karma Komisyon 1930 yılına kadar varlığını sürdürmüş ve özellikle son yıllarda Batıdan sağladığı kredilerle Yunanistan'da devletin finansal mekanizmasını kontrol eder hale gelmişti. Sağladığı hizmetlerle adeta sosyal devlet mekanizmasının yerini alan insani yardım kuruluşları Milletler Cemiyeti’nden ibaret olmayıp irili ufaklı, çok parçalı bir yapı sergilemekteydi. Bu yapı içinde ABD’nin yardım kuruluşları ise tek başına en az Milletler Cemiyeti kadar etkin bir rol oynamıştı (Giannuli, 1988).

Milletler Cemiyeti’nin tasfiye olduğu dönemde uluslararası sosyal politika hamlelerini sınırlı bir ölçüde de olsa ILO devralmıştır. Örgütün ilk ve Standing’e göre en karizmatik direktörü Albert Thomas, ILO’nun misyonunu uluslararası düzeyde refah politikalarına dayalı bir kapitalist düzen 
oluşturmak şeklinde tanımlamıştır (Standing, 2008, s.355). Polanyi ise ILO’nun kuruluş amacını "liberal ticaretin sürdürülebilirliğini sağlamak üzere uluslararası rekabet koşullarını daha eşitlikçi bir zemine oturtmak" şeklinde özetlemişti (Polanyi, 1944, s.27). Bir başka görüşe göre ILO, ABD, İngiltere ve Fransảnın Bolşeviklerin çekimine karşı kullanmak istedikleri bir örgüttü. Örgüt bünyesinde işçiler, işverenler ve hükümet bir arada temsil ediliyordu, amaç ise tarafları bir araya getirerek sınıf uzlaşısına yönlendirmekti (Smith, 1997, s.25). ILO Bolşeviklerin sınıf çatışması kavramına alternatif olarak sınıflararası uzlaşıyı savunan Amerikan ve İngiliz sendikacılı̆̆ını takip ediyordu (Anık, 1999, s.47-49).

Sınıflararası uzlaşının yolunun verimliliği arttırmaktan geçtiğini savunan Amerikan sendikacıllğı II. Dünya Savaşı sonrası Avrupa’da da Ulusal Verimlilik Merkezlerinin kurulmasını destekliyordu. Hedeflenen verimlilik artı̧̧ı ise ancak "bilimsel yönetim" ilkeleri çerçevesinde ilgili uzmanlar tarafından tasarlanabilirdi. Bu sebeple, ulusal verimlilik merkezlerine yine ABD’nin desteğiyle Avrupa’nın pek çok yerinde araştırma merkezleri eşlik ediyordu. Bir bakıma, Milletler Cemiyeti döneminin hükümetleri ve hükümet-dışı aktörleri bir araya getiren uluslararası kongreler geleneğini, (Smith, 1997, s.25) Soğuk Savaş döneminin bilimsellik söylemi çerçevesinde araştırma merkezleri, ulusal, bölgesel enstitüler ikame ediyordu. Enstitüler ve araştırma merkezleri, uluslararası politikaların üretildiği kongrelerden daha etkin ve sürdürülebilir bir araçtı. Bu enstitüler ve araştırma merkezleri bir yandan sürekli ve sürdürülebilir bir uluslararası politika platformu sağliyor, diğer yandan da "bilimsellik" vurgusuyla siyasi meşruiyet üretimine yardımcı oluyordu. Bu bağlamda, Fransa'daki Centre Intersyndical d'Etudes et de Recherche de Productivité (CIERP) bu "bilimsellik" ve ekonomik verimlilik arasındaki ideolojik eşleşmeye açık ve net bir örnek teşkil etmektedir (Carew, 2003). Bu yolla hedeflenen verimlilik artışının ardındaki ideolojik beklenti ise Standing'in deyimiyle, "emek piyasalarını düzenlemek ve sosyalizmin ilerleyişini durdurmaktı" (Standing, 2008, s.356). Bilimsellik söyleminin vücut bulduğu araştırma kuruluşları, kalkınma enstitüleri gibi unsurların ön plana çıkmasıyla birlikte yumuşak güç siyaseti de ivme kazanıyordu. ILO ise bir bakıma bu tür kuruluşların ideolojik çatı örgütü olarak işlev görüyordu.

Milletler Cemiyetiyle aynı dönemde Uluslararası Çalışma Ofisi (ILO) olarak kurulan örgüt, 1944 yılında Philadelphia Deklarasyonu'yla Uluslararası Çalışma Örgütü (ILO) olarak kendisini revize etmişti. Bu deklarasyon ILO’nun Soğuk Savaş döneminde alacağı konumu ve rolü de belirliyordu. Deklarasyonun 1(c) maddesi; herhangi bir yerdeki yoksulluk refaha her yerde tehdit oluşturur" ifadesine yer veriyordu. 2(b) ve 2(c) maddeleri ise; ILO hedeflerinin ulusal ve uluslararası politika hedefleri olarak takip edilmesi gerektiğini; ilgili ulusal ve uluslararası düzenlemelerin tanınıp tanınmayacağına bu çerçevede karar verileceğini dile getiriyordu. Deklarasyonun son maddesi ise, bu ilkelerin gelişmişlik düzeyine göre uygulanacağına, bağımlı ve bağımsız ülkelerdeki uygulama sorunlarının medeni dünyanın ortak meselesi olduğuna vurgu yapıyordu ("ILO Philadelphia Bildirgesi," 1944). Böylelikle, dönem itibarıly kolonyal yönetim altında bulunan ülkeler de kapsam alanına alınmış ve aynı zamanda sömürge düzeni meşrulaştırılmış oluyordu. 
ILO’nun Soğuk Savaş dönemindeki yönetsel yapısına baktığımızda ise küresel hedeflerini bölgesel düzeydeki örgütlenmelerle gerçekleştirmeye çalıştığını görüyoruz. Bu amaçla, ILO İtalyảnın Turin kentinde şimdiki adı International Training Centre (ILO-ITC) olan bir Uluslararası Emek Çalışmaları Enstitüsü ve Emek Eğitim Merkezi kurmuştu. Bu açıdan değerlendirildiğinde, Turin'deki merkezin Avrupa bölgesine hizmet verirken, çalışmaya konu olan Yakın ve Orta Doğu Çalışma Enstitüsünün de kendi bölgesine hizmet verdiğini söyleyebiliriz. ILO’nun yanı sira, American Federation of Labor and the Congress of Industrial Organizations (AFLCIO) ve International Confederation of Free Trade Unions (ICFTU) da yine dünyanın çeşitli stratejik noktalarında bölgesel kalkınma merkezleri, çalışma enstitüleri ve araştırma merkezleri kurmaktaydı. World Federation of Trade Unions (WFT) içinden bir grubun örgüt içindeki komünist propagandaya karşı çıkarak kurduğu ICFTU ve aynı zamanda dönem itibarıyla ILO üyesi olan AFL-CIO, dünyanın çeşitli bölgelerinde ILO ile ortak temelde hareket ediyordu. Örneğin, American Institute for Free Labor, AFL-CIO ve ICFTU tarafından Latin Amerika ve Karayipler bölgesinde çalı̧̧ma ilişkilerinin liberal politikalar ekseninde düzenlenmesine destek sağlamak amaciyla kurulmuştu (Riche, 1965). African-American Free Labor Center ve Asian American Free Labor Institute da yine AFL'nin bağlı kuruluşlarıydı (Hill,1993, s.67). Hill'in de ifade ettiği gibi Soğuk Savaş döneminde özellikle sendikal örgütlenmeler, ABD’nin denizaşırı politikalarının önemli araçlarından biri haline gelmişti. Türkiyede YODÇE’nin kuruluşu da bu gelişmelerden bağımsız değildi. YODÇẺnin misyonu ve faaliyetleri bu benzer nitelikli kuruluşlarla birlikte değerlendirildiğinde daha net anlaşılmaktır.

İkinci Dünya Savaşının ertesinde bağımsızlığını yeni kazanan ülkelerin devlet aygıtları güçlü bir sosyal politika düzenine sahip olmadıklarından bu açığın en azından bir kısmı kalkınma ve refah politikaları üretmekle görevli bilimsel-bürokratik kuruluşlarla kapatılmaya çalışılmıştır. $\mathrm{Bu}$ türden bir kuruluş olan YODÇE, özellikle çalışma yaşamının düzenlenmesi ve koşulların iyileştirilmesi yoluyla bölgesel toplumsal refaha katkı sunmaya çalışmıştır. 1960 yılında İstanbul Üniversitesi Sosyal Siyaset kürsüsünde asistan olarak çalışmaya başlayan, YODÇE faaliyetlerinde de aktif görev alan Nevzat Yalçıntaş kendisiyle yapılan sözlü tarih görüşmesinde bu konuyla ilgili şu açıklamada bulunmuştur:

“...Ama İkinci Dünya Harbi’nden sonra yepyeni bir dünya haritası çıtı ortaya. Birleşmiş Milletlerin de kurulmasıyla şu saydığımız devletlerin hepsi müstakil devletler oldu; müstakil devletler olunca o dönemin en önemli hedefi olan devletler ve milletlerin ekonomik kalkınma hedefi öne geçti ve bu da sanayileşme bağlantısına, birçok sektörlerin geliştirilmesi manasına geliyordu ki işte çalışma hayatı ortaya çıkıyordu... Fakat bu kadar güçlü olduğu bilinmeyen yepyeni bir kara güzel ortaya çıktı; o da petrol. Rengi karadır ama bu petrol ekonomisi, özellikle Orta Doğu’da önemli değişikliklere ve gelişmelere sahne olmuştur... Bunun manası nedir? Bunun manası sonuçta çalışma hayatının canlanmasıdır, iş̧̧i işveren ilişkilerinin gelişmesidir, sendikalaşmadır. Buralarda sendikalar kurulmaya başladı, sendikaların kurulmasında ILO teşkilatı ve bürosu önemli roller oynamaya başladı, bu ülkeler yavaş yavaş ILO’ya üye olmaya başladı. 
Bütün bunlar Orta Doğu ve Yakın Doğu ile teşkilatın ilişkilerini arttırdı ve bütün bunlar yepyeni bir saha ortaya çıkardı" (Cam, 2008, s.15-16).

Yalçıntaş่ın bahsettiği bu yeni sahada, Batı bloğu Soğuk Savaş koşulları altında yeni düzenin çalışma hayatına uyum göstermeye çalışan bölge ülkelerini ILO ve bağlı kuruluşlar aracılığıla denetim altında tutmaya özen gösteriyordu. Özellikle işçi örgütlenmeleri ve sendikal eğitimler gibi faaliyetlerin Yakın ve Orta Doğu’da Sovyet yanlısı eğilimlere yol açmamasına dikkat ediyorlardı.

Sovyetlerin bölgedeki yayılmacı politikalarına karşı, bu ölçülü ve kontrollü destek girişimine aslında ilk kez Birinci Dünya Savaşı sonrasında rastlanmaktadır. Bu anlamda, liberal uluslararası örgüt aklının hafızasında benzer bir deneyimin zaten var olduğu söylenebilir. Nihayetinde Sovyetler Birliği Soğuk Savaş’la birlikte kurulmamıştı. Sovyet tehdidi 1917’den beri etkin bir şekilde Batı bloğunu ortak çıkarlar etrafında birleştiriyordu. Örneğin, Birinci Dünya Savaşı sonrası Avusturya’nın yaşadığı ekonomik çöküş ve beraberinde getirdiği toplumsal kaosun olası bir Sovyet yayılmasına yol açmaması için Batı bloğu Milletler Cemiyeti eliyle Avusturya’ya geniş çaplı ekonomik destek sağlamıştı (Salter, 1923). Savaş sonrası iflas eden ülke ekonomisi ve halkın yaşadığı zorluklar karşısında Avusturya’nın Sovyetlere meyl etme potansiyelini Avrupa'ya yönelen siyasi bir tehdit olarak algılayan Batılı devletler, O zaman Milletlerarası Milletler Cemiyeti eliyle Avusturya ekonomisine finansal destek sağlayarak ayakta tutmaya çalışmışlardı. İkinci Dünya Savaşı ertesinde ise, bu ülkeler YODÇE gibi bir yumuşak güç enstrümanı aracılığıyla Türkiye ve çevre ülkelerde Sovyet yayılmacılığına karşı koyma yoluna gitmişlerdir.

Enstitü faaliyetlerinde aktif rol almış İstanbul Üniversitesi İktisat Fakültesi Sosyal Siyaset Kürsüsü emekli profesörlerinden Sabahattin Zaim kendisiyle yapılan sözlü tarih görüşmesinde bu konuyu şöyle ifade etmiştir:

\begin{abstract}
“Milletlerarası Çalışma Teşkilatı, Cemiyeti Akvam’a bağlı bir yan kuruluş olarak tesis edilmiştir. Bunun sebebi; insani hem de iktisadidir. Zahiri sebebi insanidir; milletler arasında çalışanların çalışma şartlarını düzenlemek, iyileştirmek ve standardize etmek, yeknesaklaştırmaktır. Bunların ilk kelimesi insanidir. Yani çalışanların hayat şartlarını geliştirmek, güzelleştirmek. Standardize etmek ise iktisadidir. Bunu sebebi ise şudur; 20. asrın başında İngiltere başta olmak üzere bazı ülkelerde sosyal siyaset tedbirleri gelişmeye başlamıştır. Çünkü 19 asır "laissez faire" sisteminin hâkim olduğu bir dönemdir. Karl Line’nın tabiri ile 19. asır tek kollu bir insanın uçuşuna benzer. 19. asır sadece maddi ve teknolojik yapısı ile gelişen manevi, ruhi, ahlaki ve insani cephesi felç olmuş bir toplum yapısıdır. Bu sebeple Sosyalizm ve Marksizm ekolleri çıkmıştır. Bu ekoller durup dururken çıkmadı ki... Bu dengesizliğe karşı bir reaksiyondur." (Cam, 2008b, s.12).
\end{abstract}

Buradan ILO’nun misyonunun sosyal politikaları ön plana çıkararak bir orta yol bulmak olduğu anlaşılmaktadır. Soğuk Savaşın başında YODÇE çerçevesinde girişilen çabalarla, Birinci Dünya Savaşı ertesinde Milletler Cemiyeti kapsamında uygulanan politikalar arasında bir paralellik gözlenmektedir. Bu anlamda, iki savaş arası dönem ve Soğuk Savaş dönemi sosyal politika 
girişimleri ya da müdahaleleri uluslararası düzeyde devamlılık arz etmektedir. Sendikalar özelinde, Stevens’ın belirttiği gibi, Soğuk Savaş düzeni 1920’lerde başlamıştır (Stevens, 2018). Bu iki dönem arasında kurumsal yapılar revizyona uğramış olsa da sosyal politikaları araçsallaştırma bakımından uluslararası misyon ve hedefler sabit kalmıştır. Birinci Dünya Savaşı ertesinde Milletler Cemiyeti, ABD yardım kuruluşlarıyla birlikte inisiyatifi ele alırken, İkinci Dünya Savaşı ertesinde ILO ve ABD’nin çalışma örgütü AFL sahada faaliyet göstermekte ve liberal Batı bloğunun politikalarını dünyanın çeşitli kesimlerine yaymaktaydı (Hill, 1993).

Bu sürekliliklere karşın, Soğuk Savaş politikaları bölgesel kırılmalar da yaratmıştır. Genel olarak, iki savaş arası dönemde Yakın Doğu olarak adlandırılan bölge, Soğuk Savaş döneminde Orta Doğu olarak adlandırılmıştır. İstisnai olarak, Yakın Doğu ve Orta Doğu adlandırmalarının farklı dönemlerde kullanıldı̆̆ı örneklere rastlansa da (Laçiner, 2007, s.154) Soğuk Savaş düzeninin özellikle ABD’nin girişimleriyle Orta Doğu adlandırmasından yana bir tercih ortaya koyduğu açık ve nettir (Davison, 1960). Soğuk Savaşla birlikte gelişen bu bölgesel revizyon, Türkiye’nin de uluslararası ve bölgesel konumunu önemli ölçüde etkilemiştir. Bu dönemde Marshall Planı ve NATO üyeliği Türkiye ve Yunanistan’ı Batı bloğu içinde eşleştirirken, YODÇE üzerinden girişilen faaliyetler bu kez Türkiye ile artık "Orta Doğu” olarak anılan komşu ülkeleri sosyal politika düzleminde bir araya getirmiştir.

\section{Yakın ya da Orta Doğu?}

\subsection{Açık Uçlu Bir Siyasi Coğrafyada Uluslararası Politikalar}

Modern dönemin bölgesel adlandırmaları içinde Yakın Doğu kadar sınırları belirsiz bir coğrafyaya az rastlanır. Bu kavramın ne zaman ortaya çıktığı, tam olarak hangi coğrafyaları kapsadığı ya da kapsamadığı konusunda pek çok görüş ortaya atılmıştır. Yakın Doğu’nun Soğuk Savaşla birlikte yerini Orta Doğu kavramına bırakması konusunda ise bir genel kabul mevcuttur. Bu açık uçlu siyasi coğrafyanın sınırlarını çizme çabalarına örnek olarak birkaç çalışmadan bahsedilebilir. Örneğin, Amerikan Yakın Doğu Yardım Örgütü adına uzun yıllar Türkiye’de görev yapan James Levi Barton, Yakın Doğu’nun sınırlarını çizerken, Mısır, Arabistan, Filistin, Suriye, Mezopotamya, Türk İmparatorluğu’nun tamamı, Balkan Yarımadası ve Yunanistan’ı sıralar (Barton, 1923, s.153). Diğer taraftan yakın dönem Orta Doğu tarihçisi Charles Malik ise Yakın Doğu coğrafyasının sınırlarının dönemsel olarak Hindistan'ı da içine alacak şekilde genişleyebildiğine dikkat çeker (Malik, 1948, s.3).

Yakın Doğu'nun tarifindeki sorunlar benzer şekilde Orta Doğu adlandırmasında da görülmektedir. Aslında, çağdaş Orta Doğu kavramının ortaya çıkışı herhangi bir tarihselleştirme çabasına olanak tanımayacak kadar ani bir gelişmedir. 5 Ocak 1957'de ABD Başkanı Eisenhower bugün kendi adıyla anılan doktrini açıklarken diplomatik anlamda ilk kez Orta Doğu ifadesini kullanmıştır. Bunun üzerine Dış İşleri Bakanı Dulles, Orta Doğu’nun Yakın Doğu'dan farkını ve tam olarak hangi ülkeleri içine aldığını soran Temsilciler Meclisi ve Senato üyelerine Yakın Doğu ve Orta Doğu kavramlarının aynı şeyi ifade ettiğini söylemişti. Hemen ardından, bölge 
ülkelerini tam olarak şöyle sıralamıştır: batıda Libya, doğuda Pakistan, kuzeyde Türkiye, güneyde Arap yarımadası arasında kalan bölge ve ek olarak Sudan ve Etiyopya (Davison, 1960, s.665). Eisenhower doktrininin ana fikrinin "Orta Doğu ülkelerine askeri ve ekonomik yardım" olduğunu hatırlayacak olursak (Hahn, 2006), Soğuk Savaşın bu noktadan sonra artık bir Orta Doğu boyutu kazandığını tahmin edebiliriz.

\subsection{Yakın Doğu'dan Orta Doğu'ya Geçiş Sürecinde Türkiye}

Bu noktada, Türkiye Soğuk Savaşın Orta Doğu’ya evrilen seyri açısından önemli bir bölgesel aracı konumuna gelmiştir. Soğuk Savaş döneminde Türkiye’nin Sovyet rejiminin Doğu Akdeniz ve Orta Doğu’ya yayılmasına karşı siper vazifesi gördüğüne dair bir genel kabulden bahsetmek mümkündür. Soğuk Savaş düzeni içinde Türkiye kendi başına hareket edebilen bir bölgesel güç olmasa da, konumu gereği liberal Batı bloğunun Soğuk Savaş politikaları açısından kaldıraç etkisi yaratabiliyordu. Bu konuda, Larrabee ve Lesser (2003), Türkiye’nin Avrupa, Orta Doğu, Avrasya gibi farklı sistemlerin kültürel ve siyasal periferisinde yer aldığına vurgu yaparak Meksika, Brezilya, Cezayir, Mısır, Hindistan ve Endonezya gibi ülkelerden daha farklı bir işlev gördüğüne dikkat çekmektedir. Bu konum uluslararası düzen içinde Türkiyeye sadece bölgesel değil aynı zamanda bölgelerarası bir yetenek kazandırmaktadır. Yukarıda bahsedilen Yakın Doğu'dan Orta Doğu’ya evrilme süreci Soğuk Savaş özelinde Türkiye’nin bu bölgelerarası geçişkenlik özelliğini daha da pekiştirmiştir.

ILO ve bağlı örgütlerin Türkiye aracilığıyla Orta Doğu’da bir yumuşak güç unsuru olarak etkinlik kazanmaya başlamasında özellikle başarısız ittifak girişimleri ve birtakım bölgesel siyasi gelişmeler etkili olmuştur. Soğuk Savaş döneminin başında liberal Batı bloğunun Türkiye ve bölge ülkelerini konvansiyel ittifak formlarıly bir araya getirme çabalarından istenilen sonuç alınamamıştır. Türkiye’nin 1950’lerde Orta Doğu ülkeleriyle kurduğu ittifak ilişkilerinin başında 1955 yılında kurulan Bağdat Paktı gelmektedir. Buna ek olarak, yine Amerika’nın öncülüğünde başlatılan bir başka girişim olarak Kuzey Kuşağı ittifakından da bahsedilebilir (Çelik, 2019, s.490). Bağdat Paktı platformunda Türkiye; İran, Irak, Pakistan gibi Orta Doğu ülkeleriyle bir araya gelse de bu oluşum Mısır’n muhalefetine ve Arap milliyetçiliği üzerinden bölgede oluşturduğu nüfuza takılmıştır. Devletlerarası ittifakların istenilen sonucu vermediği anlaşılınca, yukarıda bahsedilen yeni yumuşak güç unsurları devreye sokulmuştur.

Liberal Batı bloğunun İkinci Dünya Savaşı ertesinde Orta Doğu’ya yaklaşmasında Süveyş Kanalı ve Suriye krizi gibi uluslararası gelişmelerin ötesinde, bölge ülkelerinin iç siyaseti de etkili olmuştur. Laqueur'ün belirttiği üzere, 1945 sonrası dönemde komünizm Orta Doğu bölgesinde özellikle entelektüel çevrelerde sempati kazanmaya başlamıştı. Fakat yeni oluşmaya başlayan işçi örgütlenmeleri arasında henüz pek fazla yayılmamıştı (Laqueur, 2016). Bölgenin Arap milliyetçileri ve muhalif kesimleri 1950'lerin başında özellikle petrol sahaları (Hinnebusch, 2003, s.125) ve tütün gibi yabancı tekellerin etkin olduğu sektörlerde işçileri örgütlemeye başlamıştı (Abisaab, 2004). Bu durum karşısında Batı bloğu bölgede Sovyet nüfuzunu önlemek amacıyla 
ILO’yu devreye sokmuştur. Özellikle, ABD yönetimi Sovyet yayılmacılığına karşı Yunanistan ve Türkiyede Marshall planı çerçevesinde tedbirler aldıktan sonra, 1950'lerin başında rotayı Orta Doğu'ya çevirmiştir. Nasser 1952'de iktidara geldiğinde kendisini Orta Doğu'nun Thomas Jefferson’ı olarak gören Eisenhower yönetimi, 1956 Süveyş Kanalı hadisesinden sonra aynı kişiyi Mısır'ın Lenin’i olarak nitelemeye başlamıştır (Little, 2008, s.204-205). İşlemeyen devletlerarası ittifaklar, Süveyş Kanalı ve Suriye krizleri, sendikalaşma yönündeki iç politik gelişmeler ABD’yi bölgede adeta yeni bir sayfa açmaya yönlendirmiştir. Eisenhower yönetiminin Suriyede Sovyet yanlısı yönetimi devirme girişiminin başarısız olması, ABD iç siyasetinde de tepkiyle karşılanmış ve dış politikanın kötü yönetildiği eleştirileri duyulmaya başlanmıştır (Lesch, 1992, s.112). Bunun üzerine, Soğuk Savaş düzeninin artık güç siyasetine dayalı araçlardan başka enstrümanlara ihtiyaç duyduğu görülmüştür. Çalışmanın başında da belirtildiği üzere, Eisenhower bu gerekliliği bizzat ifade etmiştir.

Bu noktada, ILO'nun ABD’nin yeni Orta Doğu politikasının en büyük destekçilerinden biri olduğunu belirtmek gerekir. 1953 yılında hem ILO Genel Sekreteri Jef Rens hem de ABD Diş İşleri Bakanı Dulles, geniş kapsamlı Orta Doğu ziyaretleri gerçekleştirmişlerdi. ILO Genel Sekreteri Mısır ve çevre ülkeleri kapsayan ziyaretinden olumlu anlamda şaşırtıcı izlenimlerle dönmüştü. Özellikle, Mısır’ın sanayileşme ve modernleşme çabalarını takdirle karşılamış, bu alanda daha ileri adımlarla bu ülkeye destek verilmesi gerektiğini vurgulamıştı (Maul, 2009). ABD Dış İşleri Bakanı Dulles ise yine aynı yıl çıktığı Orta Doğu gezisinde bölge ülkelerine ortak savunma örgütü kurma önerisiyle gitmiş, fakat Pakistan dışında olumlu bir yanıt alamadan ülkesine dönmüştü. Bu ziyaretle ilgili ABD Kongresine bilgi verirken, Sovyet tehlikesine karşı kurulmak istenen güvenlik paktına Batılı ülkelerin önderlik etmesinin uygun olmadığını, bölge ülkelerinden birinin bu misyonu üstlenmesinin daha doğru olacağını belirtmişti. İşte bu noktada, Türkiye’nin Orta Doğu'daki bölgesel misyonu tekrar gündeme geldi. Eisenhower'ın yumuşak güç politikasına zemin oluşturan bu diplomatik veriler ışı̆̆ında Türkiye’nin bölgesel rolü de giderek önem kazanmaktaydı.

Özellikle, İkinci Dünya Savaşından sonra kolonyal yönetimlerin Orta Doğu'dan çekilmesiyle birlikte ABD’nin Türkiye'nin aracılığına olan ihtiyacı artmıştır. Rubin'in (2013) vurguladı̆̆ı üzere, bölgede İngiliz ve Fransız emperyalizminin yöntemlerini uygulayamayacağını anlayan ABD yönetiminin Türkiye aracılığıyla yumuşak güç unsurlarını devre koyduğu anlaşılmaktadır. Orta Doğu’ya açılmak bu dönemde ABD politikaları açısından elzemdi. ABD Başkanı Truman, Amerikan sisteminin ancak küresel ölçüde yayılabildiği müddetçe Amerika'daki varlığını ve etkinliğini sürdürebileceği görüşündeydi (Fleming, 1961, s.436). Leffler’in (1985) belirttiği gibi, ABD yönetimi bu dönemde Türkiye'ye yakın tehdit unsuru oluşturan bir Sovyet saldırısını önlemekten çok, Orta Doğu ve Doğu Akdeniz bölgesine açılma amacıyla hareket etmişti. Diğer taraftan, Sovyet dış politikası da Doğu’yu büyük ve vazgeçilmez bir unsur olarak benimsemişti. Doğu olmadan bir dünya ihtilali gerçekleştirmeye olanak yoktu. Doğu’da sömürgeci faaliyetlere karşı milliyetçi tepkiler oluşmaya başlamıştı. Bukharin’e göre, bu sömürgeci faaliyetler Sovyet rejiminin değirmenine su taşıyordu. Lenin’e göre ise, dünya devrimi emperyalizmle ezilenlerin savaşıydı ("Bakü 1920 Birinci Doğu Halkları Kurultayı”, 2000). Sonuç olarak, her iki bloğun da 
hedefe Orta Doğu’yu koyduğu noktada Kerr'in "Arap Soğuk Savaşı” olarak adlandırdığı süreç başlamış oluyordu (Kerr, 1967).

Batı bloğunun yumuşak güç siyasetiyle bölgede nüfuz oluşturmak için neden Türkiyeyi seçtiği sorusuyla ilgili Erken, Marshall’n Yakın Doğu'da sosyal değişime ancak nüfusu ağırlıkla Müslüman bir ülkenin öncülük edebileceği görüşünü hatırlatmaktadır (Erken, 2015, s.114). Yukarı da bahsedildiği üzere, Dulles de ABD Kongresine benzer bir öneri sunmuştur. Çeçen’nin de dediği gibi 1950'lilerin ikinci yarısında ABD Soğuk Savaş denklemi içinde Türkiye’yi Orta Doğu'ya yönelten bir anlayışa sahipti ve ODTÜ, TODAİE ve YODÇE gibi kuruluşları da bu yönelime uygun bir şekilde devreye sokmuştu (Çeçen, 2001, s.11).

\section{Türkiye'nin Bölgesel Rolü ve YODÇE}

\subsection{Bölgesel Bir Yumuşak Güç Merkezi Olarak Türkiye’de Kurulan Kuruluşlar}

Aslına bakılırsa, 1950'lerin başında Türkiye'de devreye sokulan tek yumuşak güç aracı YODÇE değildir. Erken'in detaylı bir şekilde ele aldığı üzere gerek ABD’nin Marshall Programı kapsamında gerekse Rockefeller Vakfı ve Ford Vakfı gibi sponsorların desteğiyle benzer nitelikte başka kuruluşlar da kurulmuş, var olanlara ise destek sağlanmıştır. Örneğin; aynı dönemde daha önce değinilen "bilimsellik söylemi" çerçevesinde Kamu Finansmanı Enstitüsü ve İsletme İktisadi Enstitüsü kurulmuştur. Harvard Üniversitesi'yle ortak program yürüten İş İdaresi Enstitüsü, Nejat Eczacıbaşı ve Vehbi Koç gibi Türkiye’nin iktisadi hayatına yön veren isimlerin aile şirketinden bir ülkenin en büyük sermayedarlarına dönüşme sürecine önemli katkılar sağlamıştır (Erken, 2018, 90-92). Prof. Hıfzı Timur ve Dr. Osman Okyar’n girişimleriyle bir Yakın Doğu Çalışmaları Enstitüsü kurulması için girişimde bulunulmuş fakat bu girişim Rockefeller Vakfı’nın desteklediği bir araştırma projesinin ötesinde kurumsal bir kimlik kazanamamışırı (Erken, 2018, s. 103, 111-112).

ABD 1950'lerin başından itibaren Türkiye'de sadece ekonomik düzene değil aynı zamanda politika yapım süreçlerine de etki eden bazı kuruluşların kurulmasına ön ayak olmuştur. Örnek'in bahsettiği Türkiye ve Orta Doğu Amme İdaresi Enstitüsü (TODAİE) bu türden kuruluşların başında gelmektedir ki TODAİE’nin Latin Amerika bölgesine yönelik Brezilyảda bir muadilinin bulunması da bu çalışmanın başında tartışıldığı üzere bu türden kurumların aynı zamanda bir uluslararası düzen unsuru olduğunu ortaya koymaktadır (Örnek, s.953). Bunun yanı sıra ABD, Pakin'in bahsettiği üzere Türkiye ve bölge ülkelerinde liberal düzenin fikri ve iktisadi liderlerini yetiştirmek üzere ikili kültürel değişim ve eğitim programlarını (Pakin, 2008), ideolojiyi kitleselleştirmek için de çeşitli yayın çalışmalarını desteklemiştir (Örnek, 2013, s.131-157).

Ancak Erken, Örnek ve Pakin'in bahsettiği kuruluşlar, Türkiyede ABD tarafından kurulan kuruluşlardır. YODÇE ise bir ILO ajansı olarak kurulmuştur. Fakat, Soğuk Savaş düzeni içinde bu ikisi arasında ideolojik bir ayrım olmadığı için kim tarafından kurulduğunun da bir önemi yoktur. Hatta Eker’in bahsettiği İş İdaresi Enstitüsü ile YODÇE’nin aynı ideolojik çerçevede 
birbirini tamamlayıcı bir işlev gördüğünü söyleyebiliriz. İş İdaresi Enstitüsü sistemin ihtiyaç duyduğu serbest müteşebbisleri yaratırken, YODÇE de bu müteşebbislerin ihtiyaç duyduğu çalışanları vücuda getirmektedir.

\subsection{YODÇE Çerçevesinde Ulusal ve Bölgesel Yumuşak Güç Uygulamaları}

$\mathrm{Bu}$ bağlamda, eğitim faaliyetleri ve kariyer geliştirme programları YODÇE faaliyetlerinin ana eksenini oluşturmaktaydı. Eğitim faaliyetleriyle hedeflenen az gelişmiş ülkelerin iş̧̧ilerine örgütlü sendikal yaşamı tanıtmak, iş̧̧i liderlerini yetiştirmek ve yukarıda açıklanan ideolojik çerçevede ulusal örgütlenmeyi sağladıktan sonra bu ulusal örgütleri uluslararası platformda bir araya getirerek liberal Batı bloğunun kendi içindeki ittifakını güçlendirmekti.

Ayrıca, yayın faaliyetleriyle de YODÇE programları yaygınlaştırılmaya çalışılıyordu. Enstitü ilk sayısı 1 Ocak 1958'de çıkmış olan bir bülten yayınlamaya başlamıştı. Bu bülten YODÇE’nin ILO’ya bağlı olduğu dönemde üç dilde yayınlanan uluslararası bir nitelik taşımaktaydı (Cam, 2008a, s.101-102). Bu bültende, sadece Türk akademisyenlerin değil aynı zamanda yabancı akademisyenlerin de yazılarına yer verilmiş, ILO'dan haberler aktarılmıştır (Cam, 2012, s.50).

YODÇE faaliyetlerine ve katılımcı profiline bakıldığında, Türkiye’nin bu kurum aracılığıyla yüksek siyaset alanında geleneksel ittifak örgütleriyle bir araya gelemeyen bölge ülkelerini birleştirdiği görülmektedir. Zaten bir yumuşak güç unsuru olarak Enstitü’nün kuruluş amacı da buna yöneliktir. Daha önce de görüşlerine yer verdiğimiz Zaim bu noktayı şöyle açılamaktadır;

"O zaman Milletlerarası Çalışma Teşkilatı, dünya da bu hedefleri gerçekleştirebilmek için bölge teşkilatları kuruyordu; Uzak Doğu’da Hindistan'da, Güney Amerika’da, Afrikảda merkezleri vardı. Orta Doğu’da bir yere kurmaları gerekiyordu, şimdi nereye kursunlar? Orta Doğu denen bu yerlerde Osmanlıdan otuz iki tane devlet çıkmış, bunların birçoğu Fas'tan tut da İran’a kadar Arap ülkeleri, devlet sayısı itibariyle kalabalık, buralarda kursa bunlar İsrail ile bir araya gelmiyorlar, tartı̧ıyorlar. Onlarda kurarsa İsrailliler gelmeyecek, İsrail’e kurarsa Araplar gitmeyecek, onun üzerine işte Türkiye’ye kurma fikri ortaya çımıştır." (Cam, 2008b, s.11-12).

ILO idaresi döneminde Enstitünün düzenlediği uluslararası eğitimlere katılan ülkeler; Yunanistan, İran, İsrail, Mısır, Lübnan, Libya, Sudan, Suudi Arabistan, Kuveyt, Somali, Fas, Birleşik Arap Cumhuriyeti’nden oluşmaktaydı (Cam, 2008a, s.97-98). Bu listeden de anlaşılacağ 1 üzere, ILO’nun Türkiye üzerinden eğitim verdiği ülkeler geniş bir alanı kapsıyordu. İlginç olan, bu listenin Soğuk Savaş düzeni içinde eski Yakın Doğu ve yeni Orta Doğu ülkelerini bir araya getirmesidir. Enstitü bu yönüyle de Yakın Doğu'dan Orta Doğu'ya geçiş sürecini ortaya koymaktadır. Örneğin Yunanistan çoğu zaman Yakın Doğu adlandırması içinde yer alırken, Orta Doğu bileşenleri arasında yer almamıştır. Aldcroft'un belirttiği gibi, iki savaş arası dönemde Avrupảnın çeperinde yer alan Yunanistan, Soğuk Savaş döneminde Yakın Doğu Orta Doğu’ya evrilirken Avrupa’nın merkezine doğru çekilmiştir (Aldcroft, Ibid.). 
1955-58 döneminde yani YODÇE’nin doğrudan ILO tarafından yönetildiği dönemde yapılan uluslararası eğitimlerin katılımcı profiline bakıldığında, "Türkiye ve Arap ülkeleri” ve "Türkiye ve Arap ülkeleri dışındaki ülkeler" şeklinde bir ayrımın ortaya çıktığı görülmektedir (Cam, 2008a, s.99). Bu da aslında Yakın Doğu’dan Orta Doğu’ya geçiş sürecinde, Orta Doğu kavramının içinin giderek Arap ülkeleriyle doldurulmaya başlandığına, Türkiye’nin ise Yakın Doğu ile Orta Doğu arasında bir yerde konumlandırıldığına işaret etmektedir. Böylesi bir ara formülün gelişiminde, Türkiye’nin Cumhuriyet devrimleriyle sergilediği Batılılaşma çabaları kadar, Türkiye-Yunanistan ortaklığının altını çizen Truman Doktrini ve Marshall yardımları da etkili olmuştur (Merrill, 2006). Sonuç olarak, Soğuk Savaş döneminde liberal bloğun sosyal politika hamleleri Türkiye’nin Doğu ile Batı arasındaki geçişkenliğini daha da pekiştirmiştir.

Diğer taraftan, Türkiye’nin Orta Doğu'daki bölgesel rolünü oynarken, Soğuk Savaş่ı yumuşak güç politikalarının hem aracı hem de alanı haline geldiğini belirtmek gerekir. Yani, liberal Batı bloğunun komünizm tehdidini önlemek için yaymaya çalıştığı sosyal politika anlayışı ve uygulamalarını sadece Orta Doğu ülkelerine ihraç etmemiş, aslında deyim yerindeyse bu senaryoyu önce kendisi satın almıştır.

Söz konusu dönem aynı zamanda, Türkiyẻnin çok partili hayata geçtiği ve buna bağlı olarak önemli siyasal dönüşümler yaşadığı bir dönemdir. Türkiyede o dönemde Soğuk Savaş düzeni içinde liberal Batı bloğunun görüşlerini paylaşan bir iktidar bulunuyordu. Bu sebeple, Türkiye bu dönemde hem ülke içinde hem de bölgede liberal bloğa paralel bir siyaset izlemiştir. ABD Dış İşleri Bakanı Dulles, Türkiye ile müttefiklik ilişkilerinin gücünden bahsederek Orta Doğu gezisine başlamış fakat Ankara’yı ziyaret programına dahil etmemişti. Dönüşte hükümetin daveti üzerine Ankara’ya da uğrayan Dulles’a Başbakan Menderes komünizmle mücadele için daha etkin çalışma ve işbirliğinin şart olduğunu söylemişti (Akman \& Zeyrek, 2013).

Dönem itibarıly Demokrat Parti’nin komünizmle mücadele stratejisi ILO’nun yumuşak güç unsurlarıyla beslenmiştir. Örneğin, 1951 yllında Türkiye Komünist Partisi’nin (TKP) 170 kadar üyesinin tutuklanması üzerine, YODÇE ile aynı ILO stratejisini takip eden AFL-CIO Avrupa temsilcisi Irving Brown şu yorumda bulunmuştur:

"Türkiye’de olduğu gibi ekonomik şartlar kötüyse, üstelik hükümet saldırgan bir politika uygulayıp insanlara yaşamı çekilmez hale getiriyorsa, özgürlük yoksa haklar yoksa işte tüm bu etkenler komünistlerin güçlenmesini sağlar... Komünizmi yenmek için sadece baskı tedbirleri değil fakat aynı zamanda, doğru ve akılcı sosyal reformların uygulanıp uygulanmayacağı konusundaki tutum gösterecektir" (Öztürk, 2004, s.46-47).

Brown bu yorumunda, Türkiye'de komünizmle mücadelede artık yumuşak güç politikasına geçişin gerekliliğini açıkça ifade ediyordu. Bu noktada, bir yumuşak güç unsuru olarak YODÇE ve diğer ILO bağlantılı kuruluşlar hem Türkiyede hem de yeni Orta Doğu'da sendikal hareketin belirli bir yönde gelişmesini sağlamıştır. "Hür" sendikacılık adı verilen bu hareket, bölgedeki Sovyet etkisiyle mücadelenin önemli bir veçhesini oluşturuyordu. Bu yeni strateji öncelikle sosyal 
politikalara ve kalkınma reformu gibi tedbirlere ağırlık vermeyi gerektiriyordu. Bununla birlikte, 1950'lerden itibaren ulusal kalkınma programlarına yüklenen anlam da değişti. Morawetz'in belirttiği gibi, bu dönemde ulusal kalkınma programları Sovyet modelini andıran planlı ekonomi pratiğinden çok komünizme meyletme potansiyeli taşıdığı düşünülen ülkelerde "yoksulluk kısırdöngüsüne" karşı geliştirilmiştir (Morawetz, 1977). Böylelikle, aslında Türkiye’de ve bölge ülkelerinde sosyal devlet kavramından ne anlaşılması gerektiği de belirlenmiş oluyordu.

Sonuç olarak, Türkiye’nin komünizmle mücadeledeki rolünü layıkıyla benimsediğinin anlaşıldığ1 noktada, YODÇẺnin Türkiye Cumhuriyeti hükümetine devri gerçekleştirildi. YODÇẺnin uluslararası dönemdeki son Müdürü M. Michel bu durumu, "Enstitüye Çalışma Vekaleti’nin bütün memurlarını yetiştirebilecek milli bir 'İ̧̧ İdaresi Mektebi' şeklini vermeyi düşünmek yerinde olacaktır," şeklinde ifade etmişti (Yakın ve Orta Doğu Çalışma Enstitüsü Bülteni,1960, s.8).

YODÇE’nin hükümete devri aynı zamanda Türkiye'deki iktidarın Soğuk Savaş düzeni içinde başlatılan misyonu devam ettirebileceğine dair bir kanaati de içinde barındırıyordu. Nitekim YODÇE’nin ulusal dönemde hem ülke içindeki hem de bölgesel misyonunu büyük ölçüde yerine getirmeye devam ettiği gözlenmektedir.

YODÇE’nin özellikle Türkiye Cumhuriyeti hükümetine devredildiği 1960 sonrası dönemde 5 Yıllık Kalkınma Planlarının oluşturulmasında etkin bir rol oynadığı görülmektedir. Dönemin YODÇE Müdürü Selahattin Birkan kalkınma planı hedefini ilgili seminerin açılış konuşmasında şu sözlerle özetliyordu:

"Yakın ve Orta Doğu Çalı̧̧ma Enstitüsü 5 günlük semineri boyunca verilecek tebliğler ve genel tartışmalarla felsefesi böylesine sosyal, hümaniter, Batılı ve demokratik esaslara dayanan bir Kalkınma Planının tanitılmasına ve olumlu tahliline yardımcı olmak istemektedir" (Birkan, 1968, s.4).

Cam’ın görüşüne göre, "kuruluş yıllarında Yakın ve Orta Doğu coğrafyasında bölgesel bir eğitim merkezi olan Enstitüde sürdürülen eğitimler 1960 sonrası azalmış, bir, üç, beş günlük bilimsel bildirilerin sunulduğu ve uygulamadaki sorunların tartışıldığı bir platforma dönüşmüştür” (Cam, 2013, s.41). Ancak, bu durumun YODÇE’nin bir yumuşak güç unsuru olarak artık misyonunu yerine getiremediği anlamına gelmediği anlaşılmaktadır. Soğuk Savaş düzeni içinde Cam’nn bahsettiği seminer faaliyetlerini YODÇE’nin ideolojik misyonunu 1960 sonrası dönemde daha da derinleştiren bir platform olarak görmek mümkündür. Örneğin, 1968 yllında bir YODÇE seminerinde Türkiye’de kooperatifçiliğin gelişiminin sosyalizm çağrışımları yapabilmesi ve bunun da sosyalist çevrelerce sahiplenilmesi ihtimaline karşı nasıl bir akademik çaba sergilendiği Prof. Fındıklığlu’nun tebliğinde açıkça ifade edilmektedir:

"Liberalizm ve Kapitalizm XVIII. asırla yavaş yavaş saltanat sürmeye başlar ve saltanatını devam ettirirken karşısına iki antitez çıkacaktır. Bunlardan biri bildiğiniz Sosyalizm, ötekisi de bir başka çeşit sosyalizm. Fakat adı başka: Kooperatizm...Türk örf ve 
teamül hukukunda "İmece" adının verildiğini hemen hatırladınız. İște kooperasyon, kooperatizm, kooperativizm, nihayet kooperatifçilik gibi muhtelif terimler de eninde sonunda işte bizim “imce” mizin ta kendisidir. Nitekim 1863’te Midhat Paşa ilk Zirai Kredi Kooperatiflerini, "Memleket Sandıkları" adı altında kurarken imece prensiplerinden ilham almış, kendisinin hazırladığı Nizamnamede de açıkça bunu zikretmiştir" (Fındıkoğlu,1968, s.4-5).

Böylelikle, millileştirme yoluyla bir sosyalizm tehdidi daha bertaraf edilmiş oluyordu. Bunun yanı sıra, YODÇE bu dönemde yayın faaliyetleriyle de ideolojik misyonunu yerine getirmekteydi. YODÇE’nin hükümete devrinden sonra seminerlerin yanı sıra yayın faaliyetleri de devam etti. Bu dönemde, daha ziyade Türkiye’nin çalışma meselelerine yönelik rapor ve kitaplar yayınlanmıştır (“Sanayide Genç ve Çocuk işçiler,” 1968; “Sanayide Kadın İşçiler,” 1968). Ancak, Batı bloğunun liberal ideolojisini destekleyen ve yayan yayın faaliyetleri de mevcuttur. Enstitü Müdürü ve Öğretim Üyesi Nüvit Ataş’in kaleme aldığı ve Enstitü’nün yayınladığı "Ekonominin Genel Bilgileri” başlıklı kitapta, serbest piyasa ekonomisine bir yumuşak geçiş tarif edilmektedir. Ataş, dönemin şartlarında bu geçişin faydasını şöyle ifade eder:

"Kamu mülkiyetine sahip olan memleketlerin her bakımdan durumlarının kuvvetli olduğu görülür. Diğer taraftan, özel mülkiyetler de kamu mülkiyetinin meydana gelişinde en büyük rolü oynar." (Ataş, 1968, s.251)

Bir başka seminerde, ulusal yönetime devredilen YODÇE’nin “üçlü iştirak modeliyle” çalışmanın başında bahsedildiği üzere, devlet, işveren ve işçiyi bir araya getiren ILO sendikal anlayışını da kararlılıkla sürdürdüğü ve yasal güvence altına aldığı görülmektedir. Enstitü Müdürü Birkan, seminer açılış konuşmasında bu durumu şu sözlerle ifade etmektedir: "Yeni Teşkilat Kanunumuz üçlü eğitim prensibi ile kamu ve özel sektör işverenleriyle işçi teşekküllerinin eğitiminde bizi rol sahibi yapmıştır” (Birkan, 1967, s.6).

YODÇE, ulusal dönemde ideolojik misyonunu sadece yurtiçinde değil, yurtdışında da sergilemeye devam etmiştir. 1960-1972 dönemini, idari yapılanmadan yola çıkarak bir içe kapanma dönemi olarak düşünmemek gerekir. Bu noktada, YODÇE’nin değişen idari yapısıyla uluslararası misyonunu birbirinden ayrıştırmak gerekir. 1967 tarihli YODÇE Bülteni’nde yer alan veriler özellikle eğitim faaliyetlerine Yakın ve Orta Doğu bölgesinden katılan ülkelerin sayısı ve profilinde bir değişiklik olmadığını, eğitim alan kişilerinin sayısının ise önemli düzeyde arttığını göstermektedir:

\footnotetext{
"Milletlerarası dönem süresince stajyer ve iştirakçi sayısı toplamı 490 olup 9 ayrı konuda tedrisat yapılmıştı. Dönem içinde yapılan 20 kursun yarısına yalnız Türk memurlar katılmış dolayısıyla bunlar milli mahiyette kalmıştır. Bu kurslara katılan Türk memurların sayısı 228'dir. On kadar milletlerarası kursa katılanların sayısı ise 188'dir. Bu kurslara katılanlar arasında 118 kişi Türkiye haricindeki 16 Orta Doğu ülkesinden gelmiştir... Milli dönem içinde bugüne kadar 71 seminer yapılmıştır. Aynı zaman
} 
fasılasında daha büyük bir bina sağlanmış, üçlü iştirak ve konu genişlemesin paralel olarak, milletlerarası dönemin 8 misli iştirakçi kaydedilmiştir. Böylece 12 yılda ve 16 ülkeden 4000 civarında yetişkin eleman Enstitü eğitim faaliyetlerine iştirak etmiş olmaktadır.” (Yakın ve Orta Doğu Çalışma Enstitüsü Bülteni, 1967, s.4-5).

YODÇE idaresinin ulusal yönetime geçtiği bu ilk dönemde, yaklaşım açısından da uluslararası misyonu sürdürme kararlılığını yönetsel düzeyde görmek mümkündür. 1960 yılına ait bir seminer yayınında Enstitü Müdürü, Melih Koçer, Yeni Teşkilat Kanununun 4. Maddesine istinaden:

"Yeni statü Enstitünün milletlerarası hüviyetine hususi ve daha geniş bir ehemmiyet tevcihini bilhassa göz önünde bulundurmuştur...Böyle bir kültür merkezinin ışı̆̆ını yalnız memleketimize inhisar ettirmek düşüncesi kafamızın en gizli köşesinde bile yer bulamaz"( Koçer, 1960, s.15).

Böylece, YODÇE’nin 1960'lı y1llarda özellikle eğitim faaliyetleri üzerinden bölgesel rolünü sürdürdügü anlaşılmaktadır. Ancak bu dönemde Yakın ve Orta Doğu ülkeleriyle temaslar devam ederken, Türkiye’nin ve dolayısıyla Bölge ülkelerinin sanayileşmiş Batılı ülkeleriyle bağları zayıflamıştır. Bu dönemde Enstitü artık kendi akademik, profesyonel kadrolarını yetiştirdiğinden, yabancı uzmanların sahadaki etkinliği de azalmıştır. Bu da, Türkiye’nin bölgesel ideolojik misyonunu sürdürürken artık eskisi kadar teknik bilgi akışı sağlayamadığı anlamına gelmektedir. Batıdan teknik bilgi akışının azalmasıyla birlikte, 1970’lere gelindiğinde bu açı̆̆ın daha çok ideolojik söylemlerle kapatılmaya çalışıldığı gözlenmektedir. 1967 tarihli YODÇE Bülteni’nde Enstitü Müdürü Birkan bu durumu; "Milletlerarası dönemde konuların daha teknik ve pratik olmasına mukabil, milli dönemde akademik, teorik çalışmalara oldukça önemli bir yer ayrılmıştır” sözleriyle açıklamaktadır (Birkan, 1967, s.3). Daha önce bahsedilen, kooperatifçilik tartışmasında olduğu gibi, bu dönemin seminer çalışmalarında sosyal, politika, nüfus, kentleşme, uluslararası çalışma hukuku gibi politika süreçleriyle ilişkili konular akademik ve teorik bir düzeyde ele alınmıştır. YODÇE’nin uluslararası döneminde çıkarılan az sayıdaki bültenlerde görülen teknik, mühendislik bilgi akışına bu dönemde rastlanmamaktadır (Jain, 1961).

1972 yılına kadar faaliyetlerini İstanbul'da sürdüren Enstitü, Çalışma Bakanlığı kararı uyarınca 1972 yılında Ankara’ya taşınmıştır. Cam’ın belirttiği üzere, Enstitü 1972'den sonra ise tamamen klasik bir bürokratik devlet kurumu haline gelmiştir (Cam 2013, s.37). Bir bakıma, Enstitü Ankara’ya taşınarak siyasi karar alıcılara yaklaşmış, fakat alınan kararlar üzerindeki etkisi aynı oranda artmamış, aksine azalmıştır. Bu noktada, Enstitünün etkinliğini kaybetmesinde 1961 Anayasasına 1970 ve 1971 yılında getirilen sınırlayıcı tedbirler de etkili olmuştur (Cam, 2012, s.61-62; Talas, 1970). Bu dönemde sayıca azalan bilimsel, eğitsel faaliyetlerle birlikte Enstitü’nün akademik, teorik yönü de zayıflamış ve bu açık giderek “iş ahlakı”, “alışkanlık” gibi kitlelere yönelik davranışsal, ideolojik söylemlerle kapatılmaya çalışılmıştır. 1995 tarihli, YODÇEM yayınının artık mühendislik alanını konu alan oldukça teknik bir meseleye dahi, "alışkanlık geliştirme”, "iş ahlakını yaygınlaştırma” gibi kavramlarla yaklaştığı görülmektedir (Erten, 1995, s.5) 
Son olarak, YODÇE’nin Soğuk Savaş düzeni içinde bölgesel misyonunu sürdürürken, 1970'lere gelindiğinde sıradan bir bürokratik devlet kurumu olarak etkinliğini giderek yitirmesini açılamak gerekir.

1970’lerde Kıbrıs sorunuyla Doğu Akdenizde ısınan sular, Soğuk Savaş’ın güç dengesini Yakın ve Orta Doğu'dan bu bölgeye doğru kaydırmıștı (Güney, 2004). 1960'lardan itibaren başlayan süreç ve özellikle 1964 Johnson Mektubuyla Türkiye’nin ABD ve genel olarak Batı bloğuyla gerilmeye başlayan ilişkileri yumuşak güç unsuru olarak desteklenen kurumlarda da yansımasını bulmuştu. Erken’in de değindiği gibi Rockefeller Vakfı gibi kuruluşlar bu dönemde günlük siyasi gerilimlerden uzak kalmaya çalışsalar da Türkiye'deki faaliyetlerini daha düşük bir profille sürüdürmek zorunda kalmışlardı (Erken, 2016, s.16). Değişen siyasi dengelerle birlikte Soğuk Savaşın eğitim ve araştırma faaliyetlerinin de rotası değişiyordu. Örneğin, İngiliz hükümeti, Kıbrıs'ta bir anti-Komünist eğitimi gerekli görüyordu, fakat bunu 1970'li yıllarda artık Türkiye aracilığıyla yapamayacağı netti. (Sutton, 2017, s.165). Bunun için başka bölgesel aktörlere ihtiyaç vardı. Zaim’in bıraktığı noktadan devam edecek olursak, bir dönem İsrail ve Arap ülkelerini YODÇE platformu üzerinden bir araya getiren Türkiye bu kez Soğuk Savaşın bir başka çatışma hattının doğrudan tarafı haline gelmişti. Böylelikle, Soğuk Savaşın Yakın ve Orta Doğu’da alevlenmesiyle aktif hale gelen YODÇE, bu kez alevlerin Doğu Akdeniże sıçramasıyla bir yumuşak güç unsuru olarak uluslararası düzen içindeki etkinliğini yitirmeye başladı ve sıradan bir ulusal bürokratik devlet aygıtı kurumuna doğru evrildi.

\section{Sonuç}

Soğuk Savaş düzeni içinde Yakın ve Orta Doğu Çalışma Enstitüsünü bölgesel bir yumuşak güç unsuru olarak tanımlayan bu çalışma, sosyal politika alanından yola çıkarak güvenlik odaklı çalışmalara bir alternatif oluşturmaktadır. Soğuk Savaş düzeni içinde varlık-yokluk meselesi haline gelen güvenlik kaygıları Soğuk Savaş düzenini tek yönlü bir biçimde algılamamıza ve özellikle bazı siyasal meşruiyet araçlarını göz ardı etmemize neden olmuştur.

Çalışmanın Türkiye ayağında ise, Soğuk Savaş koşullarında bağımsız hareket eden bir bölgesel güç olmasa bile, ülkenin yeni Orta Doğu’da devreye sokulan yumuşak güç politikalarının merkezi haline geldiğine dikkat çekilmektedir. Yakın Doğu coğrafyasının ele alınan dönemde siyasi bir müdahale ile Orta Doğu’ya dönüşmesi, Türkiye’nin uluslararası konumunu da etkilemiştir. YODÇE’nin kuruluşu ise kurumsal anlamda bu geçiş sürecini doğrudan yansıtan bir vaka olarak değerlendirilmektedir. Aynı şekilde, Enstitü’nün 1970’lerde etkinliğini yitirmeye başlaması Soğuk Savaş dengesinin bu kez Doğu Akdenize kaymasıyla ilişkilendirilmektedir.

\section{Kaynakça}

Abisaab, M. H. (2004) ““'Unruly” Factory Women in Lebanon: Contesting French Colonialism and the National State, 1940-1946”, Journal of Women's History, 16:3, 55-82. doi: 10.1353/jowh.2004.0056.

Akar, M. (2016) “Kadro: Bir 'Sınıftan Kaçış’ Teorisi”, Çalışma ve Toplum, 48:1, 229-251. 
Akman, H. Zeyrek, S. (2013) "John Foster Dulles'in Orta Doğu Gezisi, Temaslar ve Tepkiler", Avrasya Incelemeleri Dergisi, 2:2, 259-288.

Aldcroft, D. H. (2016) Europe's Third World: the European Periphery in the Interwar Years. New York, Londra: Routledge. doi: 10.1111/j.1468 - 0289.2006.00369_16.x.

Apostolides, J. M. (2010) The Metamorphoses of Tintin, Or, Tintin for Adults.Standford: Stanford University Press.

Assouline, P., Ruas, C. (2009) Hergé: The Man Who Created Tintin. Oxford University Press.

Althusser, L. (1971) Essays on Ideology. Londra, New York: Verso.

Andrews, J. Reisch, M. (1997) "Social Work and Anti-Communism",Journal of Progessive Human Services, 8:2, 29-49.

Anık, C., Arif, M. (1999) Çalışma Hayatı Ekseninde 2000'lerin Öncesi, Sonrası ve Türkiye Gerçeği. İstanbul: Vadi Yayınları.

Bağc1, H. (2001) Türk Dış Politikasında 1950'li Yillar. Ankara: METU Press.

Bakü 1920 Birinci Doğu Halkları Kurultayı Belgeleri-I (2000), İstanbul: Cumhuriyet.

Balkılıç, Ö. (2018) "On the Historiography of the Rise and Demise of the Third Worldism”, Akademik Incelemeler Dergisi, 13:2, 63-117. doi: 10.17550/akademikincelemeler.381389.

Başkaya, F. (1997) Kalkınma İktisadının Yükselişi ve Düşüşü. Ankara: İmge

Birkan, S. (1967) “Açılış Konuşması”, Sosyal Siyasetin Milli ve Milletlerarası Vasıtaları Semineri, 28.3.1967. İstanbul: YODÇE

Birkan, S. (1968) "Açılış Konuşması", II. Beş Yıllık Kalkınma Planında Sosyal Problemler Semineri, 18.6.196822.6.1968, İstanbul: T.C

Çalışma Bakanlığı YODÇE.

Carew, A. (2003) "The Politics of Productivity and the Politics of Anti-

Communism: American and European Labour in the Cold War", Intelligence and National Security, 18:2, 73 91. doi: 10.1080/026.845.2041233.130.6750.

Cam, E. (2008a) "Uluslararası Çalışma Örgütü’nün Türkiye’ye İlk Teknik Yardım Faaliyetleri Çerçevesinde 'Yakın ve Orta Doğu Çalışma Enstitüsü’nün Kuruluşu ve İstanbul Dönemi Faaliyetleri (1955-1972)”, Sosyal Siyaset Konferansları Dergisi, 55: 79-126.

Cam, E. (2008b) Çalıșma ve Sosyal Güvenlik Eğitim ve Araştırma Merkezinin Tarihi:YODÇE'den ÇASGEM'e Türkiye’de Çalışma Yaşamı Eğitimleri (1955-2007). Ankara: ÇASGEM Yayınları.

Cam, E. (2012) ÇASGEM Tarihi 1955-2011: Türkiye’de Sosyal Politika, İşs Sağlığı ve Güvenliği Eğitimleri. Ankara: ÇASGEM Yayınları.

Cam, E. (2013) "Akademiden Teknokrasiye, Teknokrasiden Bürokrasiye Türkiye’de Yetişkinlere Yönelik Sosyal Politika Eğitimlerinin Yönetimi Üzerine Bir İnceleme ve Yeni Bir Model Önerisi”, İş, Güç: The Journal of Industrial Relations \& Human Resources, 15:1, 29-51.

Çeçen, A. (2001) “Türkiye’nin Gelecek Yirmi Yılı”, ODTÜ Mezunlar Derneği’nde Yaptığı Konuşma, derleyen: Nermin Fenmen, 24.

Cassimatis, L.P. (1988) American Influence in Greece, 1917-1929. Kent, Ohio: Kent State University Press.

Çavuş, T. (2012) "Dış Politikada Yumuşak Güç Kavramı ve Türkiye’nin Yumuşak Güç Kullanımı”, Kahramanmaraş Sütçü İmam Üniversitesi İktisadi ve İdari Bilimler Fakültesi Dergisi, 2:2, 23-37.

Çelik, M. E. (2019) “İkinci Dünya Savaşı’nın Bitiminden Bağdat Paktı’na Geçen Süreçte Türkiye’nin Orta Doğu Politikası”, Türkiyat Araştırmaları Enstitüsü Dergisi, 64: 476-497. doi: 10.14222/Turkiyat4097. 
Davison, R. (1960), "Where is the Middle East”, Foreign Affairs, 38:4, 665 - 666.

Erken, A. (2015) "Rockefeller Vakfı, John Marshall ve Modern Türkiye’de Beşerî Bilimlerin Gelişimi: 19501965”, Divan: Disiplinlerarası Çalışmalar Dergisi, 38, 113-145.

Erken, A. (2016) "Negotiating Politics, Informal Networks and the Ford

Foundation Projects in Turkey during the Cold War", International Journal of Turcologia, 11: 21, 5-22. doi: 10.1080/095.922.90500533791.

Erken, A. (2018) America and the Making of Modern Turkey: Science, Culture and Political Alliances. New York: I.B. Tauris. doi: 10.12658/Nazariyat.5.1. D0064.

Erten, K. (1995) Makina ve Tesislerde İş Güvenliği, Makina ve Tezgahlarda Koruyucular ve Alınacak Güvenlik Tedbirleri. Ankara: YODÇEM.

Fahri Fındıkoğlu, "Plan ve Kooperatifler", II. Beş Yıllık Kalkınma Planında Sosyal Problemler Semineri, 18.6.1968-22.6.1968. İstanbul: YODÇE

Fleming, I. (1961) The Cold War and Its Origins. NewYork: Double Day. Giannuli, D. M. (1992) "American Philanthropy in the Near East: Relief to the Ottoman Greek Refugees, 1922-1923", Ph.D. Kent State University.

Gilboa, E. (2008) "Searching for a Theory of Public Diplomacy", The Annals of the American Academy of Political and Social Science, 616:1, 55-77. doi: 10.1177/000.271.6207312142.

Grabill, J. L. (1971) Protestant Diplomacy and the Near East: Missionary Influence on American Policy, 18101927, Minneapolis; University of Minnesota Press.

Gramsci, A. (1975) Prison Notebooks. Cilt. 2. New York: Columbia University Press.

Güney, A. (2004) “The USA’s Role in Mediating the Cyprus Conflict: A Story of Success or Failure?” Security Dialogue”, 35:1, 27-42. doi: 10.1177/096.701.0604042534

Hahn, P. L. (2006) "Securing the Middle East: The Eisenhower Doctrine of 1957", Presidential Studies Quarterly, 36 (1), 38-47. doi: 10.1111/j.1741-5705.2006.00285.x

Hayden, C. (2012) The Rhetoric of Soft Power: Public diplomacy in global contexts. Plymouth: Lexington Books.

Hill, H. (1993) “The CIA in National and International Labor Movements”, International Journal of Politics, Culture and Society, 6:3, 405-407.

Hinnebusch, R.A., Hinnebusch, R. (2003) The International Politics of the Middle East. Manchester: Manchester University Press. doi: 10.7765/978.152.6137760

Jain, K., (1961) "Yakın ve Ortadoğudaki Teknik Yardım Faaliyetleri Açısından Milletlerarası Çalışma Teşkilatı ve Az Gelişmiş Memleketler”, Sosyal Siyaset Konferansları Dergisi, çev. T. Dereli, 12, 99-113.

Kerr, M. H. (1967) The Arab Cold War, 1958-1967: A Study of Ideology in Politics. Oxford: Oxford University Press.

Khoury, P. S. (2014) Syria and the French Mandate: The Politics of Arab Nationalism, 1920-1945. Princeton: Princeton University Press.

Koçer, M. (1960) "Çalışma Hizmetlerinin İşleme ve İnkişafında Bir Çalışma Enstitüsünün Mevki ve Vazifeleri”, Miletlerarası İş İdaresi Semineri, 14.10.1960. İstanbul: YODÇE.

Laçiner, S.(2007) “Ortadoğu Diye Bir Yer Var mı?”, Uluslararası Hukuk ve Politika, 10, 153-155.

Laqueur, W. (2016) The Struggle for the Middle East: The Soviet Union and the Middle East, 1958-68. Londra: Routledge. doi: 10.4324/978.131.5622491.

Larrabee, F.S., Lesser, I.O. (2003) Turkish Foreign Policy in an Age of Uncertanity. Pittsburgh: Rand. 
Leffler, M. P. (1985) "Strategy, Diplomacy, and the Cold War: The United States, Turkey, and NATO, 19451952", The Journal of American History, 71:4, 807-825.

Lesch, D. W. (1992) Syria and the United States: Eisenhower's Cold War in the Middle East. New York: Westview Press.

Little, D. (2008) American Orientalism: the United States and the Middle East since 1945. North Carolina: University of North Carolina Press.

Makal, A. (1999) Türkiye’de Tek Partili Dönemde Çalışma İlişkileri, 1920- 1946. Ankara: İmge Kitabevi.

Maul, D. (2009) “' 'Help Them Move the ILO Way': The International Labor

Organization and the Modernization Discourse in the Era of Decolonization and the Cold War", Diplomatic History, 33:3, 387-404. doi: 10.1111/j.1467-7709.2009.00777.x

Merrill, D. (2006) "The Truman Doctrine: Containing Communism and

Modernity”, Presidential Studies Quarterly, 36:1, 27-37. doi: 10.1111/j.1741-5705.2006.00284.x.

Metinsoy, M. (2007) İkinci Dünya Savaşı̇nda Türkiye: Savaşve Gündelik Yaşam. İstanbul: Homer Kitabevi.

Morawetz, D. (1977) “Twenty-five Years of Economic Development 1950 to 1975”, The World Bank, Report, No. 10098.

Nüvit, A. (1968) Ekonominin Genel Bilgileri. İstanbul: YODÇE

Nye, J. S. (1990) “Soft Power”, Foreign Policy, 80:153-171.

Nye Jr, J. S. (2008) "Public Diplomacy and Soft Power", The Annals of the American Academy of Political and Social Science, 616:1, 94-109. doi: 10.1177/000.271.6207311699.

Nye Jr, J.S. (2009) “Get Smart: Combining hard and soft power”, Foreign Affairs, 88:4, 160-163.

Örnek, C., Üngör, Ç. (2013) Turkey in the Cold War. New York: PalgraveMacmillan. doi: 10.1057/978.113.7326690_8.

Örnek, C. (2015) Türkiye’nin Soğuk Savaş Düşünce Hayatı. İstanbul: Can Yayınları.

Örnek, C. (2012) "From Analysis to Policy: Turkish Studies in the 1950s and the Diplomacy of Ideas", Middle Eastern Studies 48:6, 941-959. doi: 10.1080/00263.206.2012.723630.

Örnek, C. (2013) “The Populist Effect': Promotion and Reception of American Literature in Turkey in the 1950s”, C. Örnek, Ç. Üngör (der.) Turkey in the Cold War: Ideology and Culture içinde. Londra: Palgrave. doi: 10.1057/978.113.7326690_7.

Öztürk, K. (2004) Amerikan Sendikacıllğı ve Türkiye İlk İlk İlişkiler: AFL- CIO’nun Avrupa Temsilcisi Irving Brown ile Söyleşi. İstanbul: TÜSTAV.

Pakin, E. (2008) “American Studies in Turkey during the 'Cultural' Cold War”, Turkish Studies, 9:3, 507-524. doi: 10.1080/146.838.40802267520.

Pamment, J. (2014) "Articulating Influence: toward a research agenda for interpreting the evaluation of soft power, public diplomacy and nation brands", Public Relations Review, 40:1, 50-59. doi: 10.1016/j. pubrev.2013.11.019.

Patterson, P. H. (2011). Bought and Sold: Living and Losing the Good Life in Socialist Yugoslavia. Cornell: Cornell University Press.

Polanyi, K. (1944) The Great Transformation. Vol. 2. Boston: Beacon Press.

Potter, E.H. (2009) Branding Canada: Projecting Canada's soft power through public diplomacy. Montreal, Londra: McGill-Queen's Press.

Riche, M. F. (1965) “The American Institute for Free Labor Development: A Catalyst for Latin American Labor Through Union Leader Training and Social Projects Sponsorship", Monthly Labor Review, 88:9, 1049-1055. 
Ross, C. (2002) "Public Diplomacy Comes of Age", Washington Quarterly, 25:2, 73-83. doi: 10.1162/016.366.00252820144.

Rubin, B. (2013) The Great Powers in the Middle East 1941-1947: The Road to the Cold War. Londra: Routledge. doi: 10.4324/978.131.5034904.

Salter, J. A (1923) "Financial Reconstruction of Austria”, The American Journal of International Law, 17:1, $115-124$.

Sanayide Genç ve Çocuk İşçiler (1968). İstanbul: YODÇE

Sanayide Kadın İşçiler (1968). İstanbul: YODÇE

Sarton, G. (1941) That They May Have Life: The Story of the American University of Beirut 1866-1941. New York: American University of Beirut.

Sbaiti, N.J. (2008) Lessons in History: Education and the Formation of National Society in Beirut, Lebanon, 1920-1960s. Georgetown University.

Smith, J., Chatfield, C. vd. (der.) (1997) Transnational Social Movements and Global Politics: Solidarity beyond the State. New York: Syracuse University Press.

Snow, N., N. J. Cull, (ed.) (2020) Routledge Handbook of Public Diplomacy. New York, Londra: Routledge. doi: 10.4324/978.020.3891520.

Sutton, C. (2017) Britain's Cold War in Cyprus and Hong Kong. Londra: Palgrave Macmillan.

Standing, G. (2008) “The ILO: An Agency for Globalization?”, Development and Change, 39:3, 355-384. doi: 10.1111/j.1467-7660.2008.00484.x.

Stevens, R. (2018) "Cold War Politics: Communism and Anti-Communism in the Trade Unions", A. Campbell, A., Fishman, vd. (der.) British Trade Unions and Industrial Politics, içinde. Londra: Routledge, 184-207. doi: 10.1177/002.200.9416658701.

Talas, C. (1970) “Değiştirilen Sendikalar Kanunu”, Ankara Üniversitesi SBF Dergisi, 25:4, 161-188.

Thompson, E. (2000) Colonial Citizens: Republican Rights, Paternal Privilege, and Gender in French Syria and Lebanon. New York: Columbia University Press.

Wang, J. (ed.) (2011) Soft Power in China: Public diplomacy through communication. New York: Springer. doi: 10.1080/17544.750.2012.723390.

Williams, R. (1953) “Idea of Culture", Essays in Criticism, 3, 239-266.

Yakın ve Orta Doğu Çalışma Enstitüsü Bülteni, (Kasım 1960), İstanbul: YODÇE.

Yakın ve Orta Doğu Çalışma Enstitüsü Bülteni (Eylül 1967), İstanbul: YODÇE.

“II. Beş Yıllık Kalkınma Planında Sosyal Problemler” Semineri, 18.6.1968- 22.6.1968, İstanbul: YODÇE.

İnternet kaynakları/internet sources

https://www.ilo.org/legacy/english/inwork/cb-policy-guide/declarationofPhiladelphia1944.pdf

erişim, 16.5.2019. 


\title{
Social Policies of the Cold War Order: The Labor Institute for Near and Middle East as a Soft Power Instrument and the Regional Role of Turkey
}

\author{
Emine Tutku VARDAĞLI
}

As an alternative to the security centered Cold War literature, this study tackles with the international social policies of the period and in this way, it discusses the changing regional position and mission of Turkey. Specifically, the regional role assumed by Turkey through the agency of the Internatioal Labor Organization (ILO) in an open-ended political geography first named as Near East and then Middle East, is investigated in-depth. The Labor Institute for Near and Middle East that was established in İstanbul by the ILO at the beginning of 1950s is examined closely, as an international organization determining the social policy norms of the Cold War order both in Turkey and in the above-mentioned region. It is indicated that this Institute, which is very little known in the political-organizational literature, functioned as an influential political maneuvering space. The mentioned institute is defined rather as a regional soft power element. Thus, the study retraces soft power politics, which is generally taken so far as a postCold War phenomenon. In this context, it is ascertained that Turkey became both the space and instrument of the soft power politics put in operation through social policies in the Cold War order. Methodologically, relying on the inputs of political history and reading the line spaces of diplomacy with an interpretive approach, this study aims at elaborating the notion of soft in in international relations literature.

The social policy dimension of the Cold War discourse is usually overshadowed by the bipolarity and security emphasizes, except a few scholarly works (Metinsoy, 2013; Örnek, 2015). At this point, it can make sense to put forward some reasons explaining this situation. For example; one can say that reserved approach of the liberal bloc against the social policy field (Andrews \& Reisch, 1997), on the other hand, the resolution of social policy matters in its own ways in the socialist order must have depreciated the significance of social policy issues. As a result of these facts, social policy matters must have lost its significance in the Cold War literature. On the other hand, life threatening aspect of the Cold War's security concerns must have relagated the other issues to the status of trivial matters. Consequently, the social policies of the Cold War era

Istanbul Aydın University, E-mail: etutkuvardagli@aydin.edu.tr 
have been discussed so less, so far. However, it does not mean that the social policy matters were irrelevant to the Cold War order.

Social policy programs of the era are defined as the soft power instruments of the Cold War order. Specifically, it is underlined that the soft power instruments were in operation in the labor relations and trade union movements. The impacts of these soft power instruments in Turkey and also in the region which was nominally transferred from the Near East to the Middle East is analyzed in depth. Moreover, the appointed role of Turkey as a "regional soft power centre" is discussed in reference to the domestic political developments in the country. So that, whole picture covers the relations of Turkey with the international organizations along with its internal dynamics.

The notion of 'soft power' is usually presented as a post-Cold War phenomenon in reference to the studies of Nye, who coined the 'soft power' term for the first time. This study makes a scholarly remark that Nye himself admitted that the soft power policies were in operation during the Cold War also (Nye, 2008, s.94). The Labor Institute for the Near and Middle East, which is placed at the heart of this study as a case, is evaluated as a national and regional soft power instrument. However, it could have been evaluated alternatively as a ideological instrument or a public diplomacy instrument. For this reason, it is crucial here to differentiate these concepts from one another. To start with the notion of ideology, it should be noted it is usually defined in reference to the works of Gramsci and Althusser. According to Gramsci, ideology is a superstructural element permeates to the society by means of culture in order to accommodate society into the dominant economic order (Gramsci, 1975, s.150-151). Taking a step further Althusser explains how ideology is extended to society through the state apparatus (Althusser, 1971). Moreover, Williams displays how it operates through popular culture in our day (Williams, 1953). So that it comes out that ideological instruments operate through culture. But the Labor Institute under question does not follow this path as it is understood from its activities and publications. It targets specifically the employees, employers and the state as the decision maker authority. This tripartite formulation reminds us the liberal syndical developed against the Soviet regime in the aftermath of the First World War and elaborated as an influential policy approach by the help of scientific institutions in the aftermath of the Second World War.

Alternatively, the Labor Institute in question and its counterparts could have been evaluated also as a public diplomacy instrument. However, the ambiguity of this notion has given way to the endless discussions today (Gilboa, 2008, p.56). Therefore, it will be safe to understand this notion in context. It is observed that this concept is generally used to refer to the ways to influence public opinion for a particular political objective, especially when there is a diplomatic negotiation between parties (Ross, 2002). From this point of view, one can see that public diplomacy initiatives are usually used in the context of conflict resolution like affecting the bilateral negotiations between the Arabs and Israel or the parties on the Cyprus Island (Snow ve Cull, 2020). Therefore, defining the Labor Institute at hand as a public diplomacy instrument would not be appropriate either. 
Regarding the national and regional impacts of this soft power instrument, the study puts forward that Turkey as the host of this Institute has been transformed since the early 1950s into a regional soft power center bringing the parties to the table to further the objectives of the liberal bloc in the Cold War order. It is emphasized that in a time period giving way to the emergence of presentday Middle East, the role of Turkey as an intermediary of the liberal bloc in the region became more significant. However, when the power balances of the Cold War order shift to the Eastern Mediterranean since the mid-1960s due to the Cyprus question, the role of the country has been diminished along with the significance of the Labor Institute for the Near and Middle East, which was relegated to the status of a noteless national bureaucratic organ. 